Tsaqofiya : Jurnal Pendidikan Bahasa dan Sastra Arab

Vol. 4 No. 1 Januari 2022, 126-135

P-ISSN : 2685-7022, E-ISSN : 2685-7103

DOI: $10.21154 /$ tsaqofiya.v4i1.49

\title{
Analisis Butir Soal Ujian Tengah Semester Bahasa Arab Kelas XII Di SMA Al- Izzah IIBS Malang
}

\author{
Rachmad Ramadhan' ${ }^{1}$, Fasich Nur Firdaus ${ }^{2}$
}

\author{
UIN Maulana Malik Ibrahim Malang \\ rachmadramadhan689@gmail.com,fasichnoerfirdaus7@gmail.com
}

\begin{abstract}
Abstrak
Penelitian bertujuan untuk menganalisis ujian tengah semester ganjil mata pelajaran bahasa Arab siswa kelas X-IPS di SMA Al-Izzah IIBS Malang tahun 20202021. Tujuannya, agar pengajar bahasa arab mampu membuat alat ukur yang baik dalam mengukur pemahaman siswa, penelitian ini menggunakan pendekatan kualitatif melalui wawancara, observasi, dokumentasi dengan model penumpulan data yang didapatkan dari lembar soal siswa. kemudian mereduksi data-data, menyajikan data, dan menarik kesimpulan untuk disajikan sebagai kesimpulan akhir. Untuk memperkuat data yang telah ditemukan, peneliti menerapkan triangulasi sebagai Teknik pengujian keabsahan data. Hasil penelitian menunjukkan : (1) dengan mereduksi data-data, menyajikan data, dan menarik kesimpulan untuk disajikan sebagai kesimpulan akhir. Untuk memperkuat data yang telah ditemukan, peneliti menerapkan triangulasi sebagai Teknik pengujian keabsahan data (2) pada tes tulis, jenis tes yang diterapkan merupakan bentuk tes pilihan ganda. Pada tes tersebut butir soal terdiri dari 25 butir soal yang mana setiap soal memiliki 5 pilihan jawaban. Pada soal pertama guru memberikan pertanyaan mengenai pengertian. Sehingga siswa tidak hanya mengetahui kaidah-kaidah Bahasa Arab akan tetapi perlu juga memahami pengertian dari unsur-unsur Bahasa Arab yang dipelajari. Pada pertanyaan kedua guru memberikan pertanyaan yang mengharuskan siswa untuk menganalisis soal untuk mencari jawaban. Di soal tersebut guru memberikan ayat al-Qu'an sebagai kalimat untuk dianalisis dan ditentukan melalui pilihan ganda yang tersedia. Dan pada soal ketiga guru memberikan soal yang mengharuskan siswa memahami kaidah-kaidah Bahasa Arab. Pada soal tersebut guru memberikan pertanyaan untuk merangkai kalimat Bahasa Arab, namun karena soal ini berbentuk pilihan ganda, jadi siswa hanya perlu memilih jawaban yang diminta guru.
\end{abstract}

Kata Kunci: Butir Soal, Ujian Tulis \& Ujian Lisan, Uji Keabsahan data

\section{Abstract}

The focus of this research is to analyze the odd mid-semester exams for Arabic subjects for class X-IPS students at SMA Al-Izzah IIBS Malang in 2020-2021. The goal, so thatArabic language teachers are able to make good measuring tools in measuring student understanding, this study uses a qualitative approach through 
interviews, observations, documentation with data collection models obtained from student question sheets. then reduce the data, present the data, and draw conclusions to be presented as the final conclusion. To strengthen the data that has been found, the researcher applies triangulation as a technique for testing the validity of the data. The results showed: (1) by reducing the data, presenting the data, and drawing conclusions to be presented as the final conclusion. To strengthen the data that hasbeen found, the researcher applies triangulation as a technique of testing the validity of the data. (2) on the written test, the type of test applied is a multiple choice test. In this test, there are 25 questions in which each question has 5 answer choices. In the first question the teacher asks questions about understanding. So that students not only know the rules of the Arabic languagebut also need to understand the meaning of the elements of the Arabic language being studied. In the second question the teacher gives questions that require students to analyze the questions to find answers. In this question, the teacher gives verses of the Qur'an as a sentence to be analyzed and determined through the multiple choices available. And in the third question the teacher gives questions that require students to understand the rules of Arabic. In this question, the teacher asks questions to compose Arabic sentences, but because this question is in the formof multiple choice, students only need to choose the answer asked by the teacher.

Keywords: Items, Written \& Oral Examination, Data Validity Test

\section{Pendahuluan}

Tes adalah alat atau prosedur yang dipergunakan dalam rangka pengukuran dan penilaian; dan testing berarti saat dilaksanakannya atau peristiwa berlangsungnya pengukuran dan penilaian. ${ }^{1}$ Kiranya dapat dipahami dalam dunia pendidikan tes juga bisa dikatakan cara yang dapat dipergunakan dalam rangka pengukuran dan penilaian di bidang pendidikan, yang berbentuk pemberian tugas baik berupa pertanyaan-pertanyaan yang harus dijawab atau perintah-perintah yang harus dikerjakan sehingga dapat dihasilkan nilai yang melambangkan tingkah laku atau prestasi tes. $^{2}$ Tes bahasa, khususnya tes bahasa Arab merupakan alat untuk mengukur kemampuan dan performansi bahasa Arab siswa. ${ }^{3}$ Menurut Sri, pengukuran didefinisikan sebagai penetapan suatu angka terhadap suatu subjek dengan cara sistematik. ${ }^{4}$ Hasil pengukuran yang berupa angka/skor diharap

\footnotetext{
${ }^{1}$ Moh Ainin, Metodologi Penelitian Bahasa Arab (Malang: Hilal Pustaka, 2016).

${ }^{2}$ Abdul Kadir, "Menyusun Dan Menganalisis Tes Hasil Belajar," Al-Ta'dib: Jurnal Kajian Ilmu Kependidikan 8, no. 2 (2015): 70-81.

3 Ahmad Syamsul Ma'arif, "Sighah Ikhtibarat Al-'Arabiyyah Fi Dui Al-Ikhtibar Al-Mutqn (TOAFL)," Jurnal Al Bayan: Jurnal Jurusan Pendidikan Bahasa Arab 9, no. 2 (2017): 160-73.

${ }^{4}$ Moh Matsna and Erta Mahyudin, "Pengembangan Evaluasi Dan Tes Bahasa Arab," Tangerang Selatan: Alkitabah, 2012.
} 
mencerminkan kemampuan peserta tes sebenarnya. ${ }^{5}$

Sedangkan evaluasi adalah kegiatan atau proses penentuan nilai pendidikan, sehingga dapat diketahui mutu atau hasil-hasilnya. ${ }^{6}$ Senada dengan Ridho, evaluasi merupakan salah satu komponen penting dalam pendidikan, khususnya evaluasi hasil pembelajaran.7 Aktivitas pendidikan menuntut adanya pengalaman belajar dari peserta didik, yang dimaksudkan untuk mencapai tujuan (menguasai kompotensi tertentu). ${ }^{8}$ Di sinilah penilaian dibutuhkan untuk melihat sejauh mana kompetensi yang telah dikuasai oleh peserta dalam bentuk hasil belajar yang diperlihatkan setelah mereka menempuh pengalaman belajar. ${ }^{9}$

Apabila penilaian merupakan salah satu bagian penting dalam rangkaian proses pembelajaran dalam pendidikan ${ }^{10}$, maka setiap pembelajaran perlu dilakukan penilaian. ${ }^{11}$ Oleh karenanya penilaian hasil belajar dapat menentukan baik tidaknya pendidikan. Sehingga, ketepatan penilaian hasil belajar memberikan dampak yang sangat signifikan terhadap upaya peningkatan mutu pendidikan di sekolah. Keterkaitan antara tes, pengukuran dan penilaian adalah hasil belajar baru dapat dilakukan dengan baik dan benar jika menggunakan informasi yang diperoleh melalui pengukuran hasil belajar dengan menggunakan tes sebagai alat ukurnya. ${ }^{12}$

Tes yang baik harus memenuhi validitas rasional yaitu validitas isi dan validitas konstruk dan validitas empirik. Kegunaan tes pengukuran dan penilaian dalam pendidikan antara lain adalah untuk seleksi, penempatan, diagnosa, remedial, umpan balik, motivasi dan membimbing, perbaikan Kurikulum, program pendidikan serta pengembangan ilmu. Sedangkan analisis butir adalah uji lapangan dari suatu tes atau soal. Keberadaannya sebagai alat konfirmasi kualitas soal. Setelah diketahui

\footnotetext{
5 Muhbib Abdul Wahab, "Pembelajaran Bahasa Arab Di Era Posmetode," Arabiyat: Jurnal Pendidikan Bahasa Arab Dan Kebahasaaraban 2, no. 1 (2015): 59-74.

6 Matsna and Mahyudin, "Pengembangan Evaluasi Dan Tes Bahasa Arab."

7 Ubaid Ridho, "Evaluasi Dalam Pembelajaran Bahasa Arab," An Nabighoh 20, no. 01 (2018): $19-26$.

8 Yayat Hidayat, "Teori Perolehan Dan Perkembangan Bahasa Untuk Jurusan Pendidikan Bahasa Arab," Maharaat: Jurnal Pendidikan Bahasa Arab 1, no. 01 (2018): 24-40.

${ }_{9}$ Muhammad Zulkifli, "Analisis Bentuk Evaluasi Kurikulum 2013 Mata Pelajaran Bahasa Arab Di MI," Al-Madrasah: Jurnal Pendidikan Madrasah Ibtidaiyah, 2018.

10 Nurgiyantoro Burhan, "Penilaian Pembelajaran Bahasa Berbasis Kompetensi," Yogyakarta: BPFE-Yogyakarta, 2014.

11 Wahab, "Pembelajaran Bahasa Arab Di Era Posmetode."

12 Amir Rudin, "Analisis Butir Soal Ujian Kenaikan Kelas Mata Pelajaran Bahasa Arab Kelas VIII Di MTs Modern Al Azhary Ajibarang Tahun Pelajaran 2015/2016” (IAIN, 2016).
} 
bahwa soal tersebut lemah dalam hal daya beda, terlalu sukar atau terlalu mudah serta pengecohnya buruk maka itu harus jadi umpan balik bagi pembuat tes untuk melihat ulang kesalahan apa yang terjadi pada soal tersebut. ${ }^{13}$ Analisis butir dapat dilakukan secara kualitatif, dalam kaitannya dengan ciri-ciri statistiknya. Butir soal objektif dapat dianalisis secara lebih akurat dan bertanggung jawab sehingga dapat diketahui kelemahannya secara tepat. Butir soal tes objektif dapat digunakan berulang-ulang, asalkan tidak dalam perangkat tes yang sama. Oleh karena itu, ada manfaat atau kegunaan analisis butir soal, kemudian direvisi sehingga butir soal yang kurang baik kontruksinya dapat diperbaiki. ${ }^{14}$

Proses evaluasi yang seringkali digunakan oleh madrasah dalam menentukan penilaian pada setiap semesternya adalah ujian tengah semester. Seperti kebanyakan sekolah-sekolah lainnya, SMA Al-Izzah yang berbasis Internasional juga menggunakan ujian tengah semester dalam menentukan penilaian dan pencapai dari tujuan pembelajaran. Peneliti tertarik untuk meneliti mengenai proses ujianharian di SMA tersebut dengan memfokuskan penelitian terhadap butir soal yang digunakan dalam ujian tengah semester. Adapun tujuan dari penelitian ini yaitu untuk menganalisis butir soal kelas 10 pelajaran bahasa arab kelas 10 SMA Al-Izzah IIBS Malang. Untuk mencapai tujuan yang diinginkan maka peneliti merumuskan rumusan masalah sebagai berikut: (1) bagaimana butir soal ujian lisan yang digunakan dalam pelaksanaan evaluasi pembelajaraan bahasa arab melalui ujian tengah semester kelas 10 Sma Al Izzah IIBS?, (2) dan bagaimana butir soal ujian tulis yang digunakan dalam pelaksanaan evaluasi pembelajaraan bahasa arab melalui ujian tengah semester kelas 10 Sma Al Izzah IIBS?.

\section{Metode}

Jenis penelitian ini merupakan penelitian kualitatif deskriptif, yang mana peneliti berusaha mengungkap data-data dan menyajikannya dalam bentuk deskriptif yang berupa kata- kata maupun ungkapan fakta terkait fenomena yang diamati. Dalam penelitian ini peneliti berusaha mengungkap data mengenai butir soal ujian tengah semester pada kelas XII di SMA Al-Izzah. Penelitian ini dilaksanakan di SMA Al-Izzah

13 Muhammad Rizal, Syihabuddin Syihabuddin, and Mad'ali Mad'ali, "Evaluasi Pembelajaran Bahasa Arab Dengan Memanfaatkan Aplikasi MiSK," Tsaqofiya: Jurnal Pendidikan Bahasa Dan Sastra Arab 3, no. 2 (2021): 199-213.

14 Kadir, "Menyusun Dan Menganalisis Tes Hasil Belajar." 
dengan objek penelitian yaitu soal-soal ujian tengah semester di SMA Al-Izzah. Teknik pengumpulan data yang peneliti terapkan dalam penelitian ini yaitu dengan melakukan observasi terhadap objek penelitian, wawancara, dan mendokumentasikan hal-hal yang dianggap penting sebagai data pendukung dalam penelitian ini. Dalam menelusuri data di lapangan, peneliti melakukan Langkahlangkah yaitu dengan mereduksi data-data, menyajikan data, dan menarik kesimpulan untuk disajikan sebagai kesimpulan akhir. Untuk memperkuat data yang telah ditemukan, peneliti menerapkan triangulasi sebagai teknik pengujian keabsahan data.

\section{Hasil dan Pembahasan}

Ujian Tengah Semester menjadi salah satu bentuk evaluasi pembelajaran Bahasa Arab di SMA Al-Izzah. Bentuk soal ujiantengah semester yang digunakan merupakan bentuk soal pilihan ganda. Diawal proses ujian guru memberikan instruksi diantaranya melakukan doa sebelum memulai ujian, dan menuliskan identitias secara lengkap pada lembar jawaban yang telah disediakan pengawas ujian. Untuk menentukan tingkat penilaian siswa, maka guru mengklasifikasikan soal berdasarkan tingkatannya dengan 50\% soal yang terbilang mudah, 25\% soal sedang, dan 25\% soal sulit. Dalam pelaksanaannya SMA Al-Izzah menggunakan 2 bentuk tes yaitu tes lisan dan tertulis.

Pada tes lisan tes ini berupa pertanyaan dan jawaban. Evaluator/guru mengajukan pertanyaan (wawancara) langsung kepada siswa. Ujian lisan di SMA AlIzzah digunakan untuk mengevaluasi hasil belajar berupa kemampuan mengungkapkan ide dan pendapat secara lisan. Ujian lisan ini dianggap relatif penting dalam penilaian pada keterampilan berbicara. Ujian lisan ini juga digunakan untuk melakukan penilaian kompetensi sebagai bagian dari kegiatan pembelajaran rutin. Adapun bentuk tes lisan yang digunakan di SMA al-Izzah dapat kita lihat pada table berikut ini:

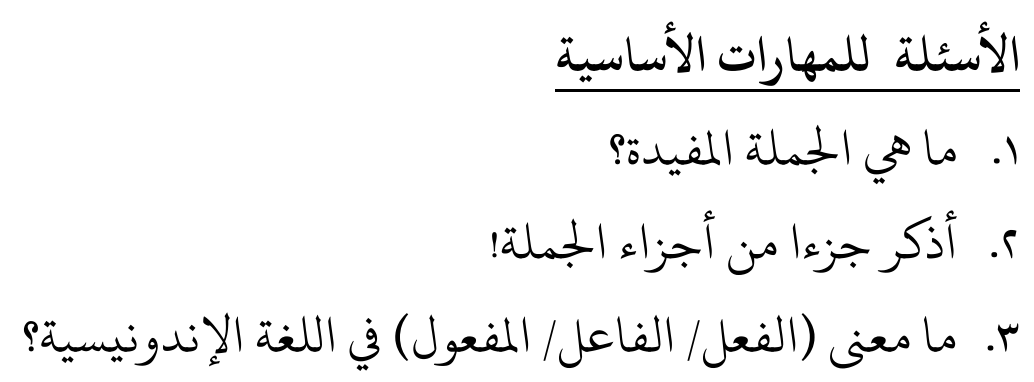




$$
\text { ع. عين العل/ الفاعل من هذه الجملة (أن يختار المدرس واحدا من الجملة) }
$$

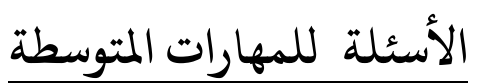

ا. كـم قسما ينقسم الفعل باعتبار زمنه؟ ؟. عين اسم إنسان/ اسم جماد من هذه الجملة!

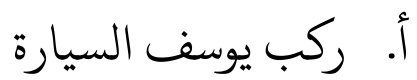
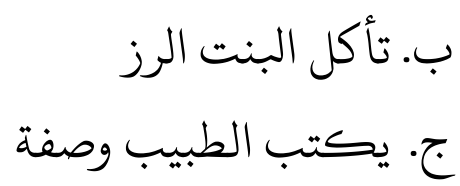

r. عين نوع الفعل باعتبار زمنه من الجملة الآتية!

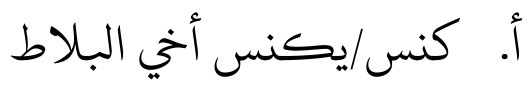

ب. كنست/تككتب المدرسة على السبورة ج. جلس/بيجلس أبي على المقعد

الأسئلة للمهارات المتقدمة ا. أ. ما هي أجزاء الجملة؟ ؟. ما الفرق بين الجملة الإسمية والفعلية؟

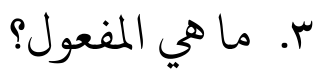
ع. اجعل جملة مفيدة تتركب من الفعل والاسم والحرف!

Soal diatas merupakan bentuk soal ujian lisan yang digunakan pada SMA AlIzzah. Pada ujian lisan yang dilakukan di sekolah tersebut, soal yang digunakan dibagi dalam tiga tahapanatau tingkatan, yaitu soal kategori mudah, sedang, dan sulit. Pada soal dengan kategori mudah,guru menanyakan kepada siswa mengenai dasardasar pelajaran Bahasa Arab, baik daripengertian, arti dari kata atau kalimat, hingga menentukan fiil dan fail pada sebuah kalimat. Dalam menentukan kata, guru memberikan bentuk kalimat yang mudah yang disesuaikan dengan kategori soal 
yang diberikan. Selanjutnya pada kategori soal sedang, guru memberikanpertanyaan kepada siswa mengenai pembagian dari fiil. Pada kategori tersebut juga guru memberikan soal yang mengharuskan siswa memilih kata yang dimaksud pada kalimat yang guru berikan. Lalu pada soal kategori sullit, guru memberikan soal mengenai perbedaan unsur Bahasa Arab satu dengan yang lainnya. Dengan mengkategorikan soal pada kategori mudah, sedang, dan sulit menjadikan soal lebih bervariatif dan tidak terbilang mudah dan diremehkan.

Selain tes lisan, SMA al-Izzah juga menerapkan ujian tulis sebagai bahan evalusi pembelajaran Bahasa Arab. Bentuk tes tulis biasa disebut juga dengan tes objektif dan bentuktes objektif yang digunakan adalah bentuk tes pilihan ganda. Butir soal tes bentuk pilihan gandaini merupakan salah satu bentuk tes obyektif yang paling luwes dan banyak dikembangkan akhir-akhir ini, karena dapat digunakan untuk mengukur berbagai tataran pengetahuan dari yang sederhana sampai yang kompleks. Tes pilihan ganda terdiri atas bagian pokok soal/pertanyaan yang disebut STEM, dan bagian alternatif jawaban yang disebut OPTIONS. Opsi jawaban, terdiri atas: satu jawaban BENAR, yaitu kunci jawaban, dan beberapa alternatifjawaban yang disebut pengecoh (distraktor). ${ }^{15}$ Adapun bentuk tes pilihan ganda dapat kita lihat di bawah ini:

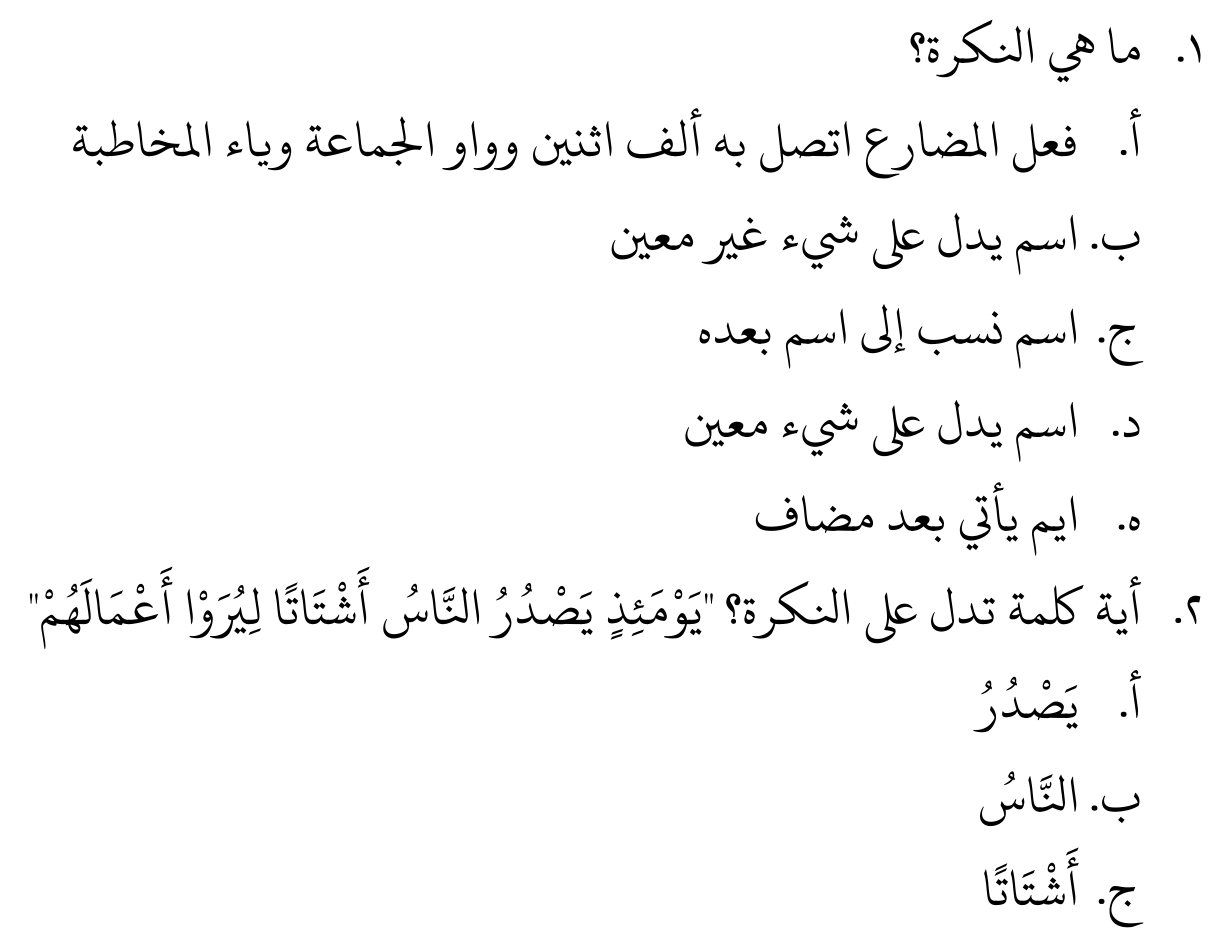

15 Amat Jaedun, “Teknik Perakitan Soal-Soal Ulangan Harian Dan Semester" (Universitas Negeri Yogyakarta, n.d.). 


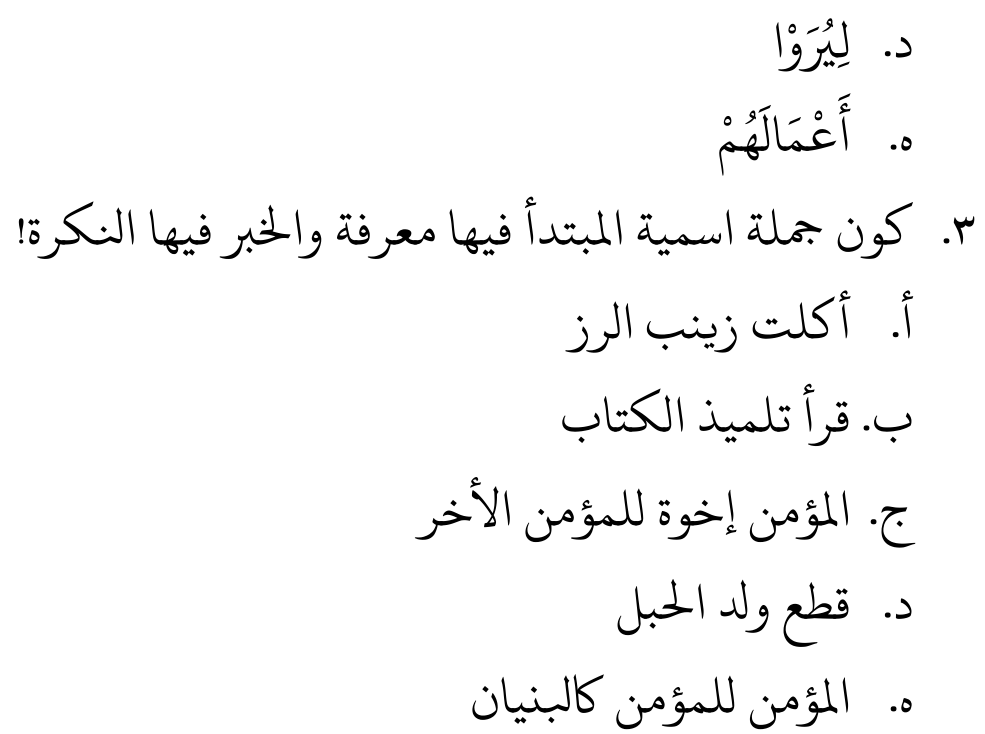

Soal di atas merupakan bentuk soal yang digunakan dalam ujian sebagai tolak ukur melihat pemahaman siswa dalam memahami pelajaran Bahasa Arab yang telah diajarkan. Soal terdiri dari 25 butir soal yang mana setiap soal memiliki 5 pilihan sebagai jawaban. Pada soal pertama guru memberikan pertanyaan mengenai pengertian. Sehingga siswa tidak hanya mengetahui kaidah-kaidah Bahasa Arab akan tetapi perlu juga memahami pengertian dari unsur-unsur Bahasa Arab yang dipelajari. Pada pertanyaan kedua guru memberikan pertanyaanyang mengharuskan siswa untuk menganalisis soal untuk mencari jawaban. Disoal tersebut guru memberikan ayat al-Qu'an sebagai kalimat untuk dianalisis dan ditentukan melalui pilihan ganda yang tersedia. Dan pada soal ketiga guru memberikan soal yang mengharuskan siswa memahami kaidah-kaidah Bahasa Arab. Pada soal tersebut guru memberikan pertanyaan untukmerangkai kalimat Bahasa Arab, namun karena soal ini berbentuk pilihan ganda, jadi siswa hanya perlu memilih jawaban yang diminta guru. Berdasarkan bentuk soal diatas menguatkan pendapat oleh Wiersma dan Jurs dalam I Wayan Koyan menyatakan bahwa terdapat dua bentukutama butir tes, yang secara umum disebut tes objektif dan esai, yang masing-masing memilikiformat yang bervariasi. Selanjutnya dinyatakan bahwa istilah butir tes objektif secara umum berhubungan dengan butir jawaban pilihan (selected response items). Sedangkan butir tes esai adalah salah satu bentuk dari butir jawaban tersusun (constructedreasponse items) (Koyan, 2012)

\section{Simpulan}

Berdasarkan hasil penelitian yang peneliti temukan dan kemukakan diatas 
memperjelas bahwa tes yang digunakan sebagai bahan evalusi pada SMA al-izzah merupakan bentuk tes lisan dan tertulis. Pada ujian lisan yang dilakukan di sekolah tersebut, soal yang digunakan dibagi dalam tiga tahapan atau tingkatan, yaitu soal kategori mudah, sedang, dan sulit. Dengan mengkategorikan soal pada kategori mudah, sedang, dan sulit menjadikan soal lebih bervariatifdan tidak terbilang mudah dan diremehkan. Kemudian pada tes tulis, jenis tes yang diterapkan merupakan bentuk tes pilihan ganda. Pada tes tersebut butir soal terdiri dari 25 butir soal yang mana setiap soal memiliki 5 pilihan jawaban. Pada soal pertama guru memberikan pertanyaan mengenai pengertian. Sehingga siswa tidak hanya mengetahui kaidahkaidah Bahasa Arab akan tetapi perlu juga memahami pengertian dari unsur-unsur Bahasa Arab yang dipelajari. Pada pertanyaan kedua guru memberikan pertanyaan yang mengharuskan siswa untuk menganalisis soal untuk mencari jawaban. Disoal tersebut guru memberikan ayat al-Qu'an sebagai kalimat untuk dianalisis dan ditentukan melalui pilihan ganda yang tersedia. Dan pada soal ketiga guru memberikan soal yang mengharuskan siswa memahami kaidah-kaidah BahasaArab. Pada soal tersebut guru memberikan pertanyaan untuk merangkai kalimat Bahasa Arab,namun karena soal ini berbentuk pilihan ganda, jadi siswa hanya perlu memilih jawaban yangdiminta guru.

\section{Daftar Pustaka}

Ainin, Moh. Metodologi Penelitian Bahasa Arab. Malang: Hilal Pustaka, 2016.

Burhan, Nurgiyantoro. "Penilaian Pembelajaran Bahasa Berbasis Kompetensi." Yogyakarta: BPFE-Yogyakarta, 2014.

Hidayat, Yayat. "Teori Perolehan Dan Perkembangan Bahasa Untuk Jurusan Pendidikan Bahasa Arab." Maharaat: Jurnal Pendidikan Bahasa Arab 1, no. 01 (2018): 24-40.

Jaedun, Amat. “Teknik Perakitan Soal-Soal Ulangan Harian Dan Semester.” Universitas Negeri Yogyakarta, n.d.

Kadir, Abdul. "Menyusun Dan Menganalisis Tes Hasil Belajar.” Al-Ta'dib: Jurnal Kajian Ilmu Kependidikan 8, no. 2 (2015): 70-81.

Ma'arif, Ahmad Syamsul. “Sighah Ikhtibarat Al-'Arabiyyah Fi Dui Al-Ikhtibar Al-Mutqn (TOAFL)." Jurnal Al Bayan: Jurnal Jurusan Pendidikan Bahasa Arab 9, no. 2 (2017): 160-73.

Matsna, Moh, and Erta Mahyudin. "Pengembangan Evaluasi Dan Tes Bahasa Arab." Tangerang Selatan: Alkitabah, 2012. 
Ridho, Ubaid. "Evaluasi Dalam Pembelajaran Bahasa Arab." An Nabighoh 20, no. 01 (2018): 19-26.

Rizal, Muhammad, Syihabuddin Syihabuddin, and Mad'ali Mad'ali. "Evaluasi Pembelajaran Bahasa Arab Dengan Memanfaatkan Aplikasi MiSK." Tsaqofiya: Jurnal Pendidikan Bahasa Dan Sastra Arab 3, no. 2 (2021): 199-213.

Rudin, Amir. "Analisis Butir Soal Ujian Kenaikan Kelas Mata Pelajaran Bahasa Arab Kelas VIII Di MTs Modern Al Azhary Ajibarang Tahun Pelajaran 2015/2016." IAIN, 2016.

Wahab, Muhbib Abdul. "Pembelajaran Bahasa Arab Di Era Posmetode." Arabiyat: Jurnal Pendidikan Bahasa Arab Dan Kebahasaaraban 2, no. 1 (2015): 59-74.

Zulkifli, Muhammad. "Analisis Bentuk Evaluasi Kurikulum 2013 Mata Pelajaran Bahasa Arab Di MI.” Al-Madrasah: Jurnal Pendidikan Madrasah Ibtidaiyah, 2018. 